\title{
Inter-municipal cooperation based on Institutional Collective Action: the effects of public health consortia in Brazil
}

\author{
Alex Bruno Ferreira Marques do Nascimento ${ }^{1}$ \\ Antônio Sérgio Araújo Fernandes ${ }^{2}$ \\ Hironobu Sano ${ }^{3}$ \\ Eduardo Jose Grin ${ }^{4}$ \\ Hugo Consciência Silvestre 5
}

1 Universidade Federal de Campina Grande / Unidade Acadêmica de Gestão Pública; Programa de Pós-Graduação em Administração, Campina Grande / PB - Brazil

2 Universidade Federal da Bahia / Escola de Administração, Núcleo de Pós-Graduação em Administração, Salvador / BA - Brazil

3 Universidade Federal do Rio Grande do Norte / Departamento de Administração Pública e Gestão Social, Natal / RN - Brazil

${ }^{4}$ Fundação Getulio Vargas / Escola de Administração de Empresas de São Paulo, São Paulo / SP - Brazil

${ }^{5}$ Universidade da Integração Internacional da Lusofonia Afro-Brasileira / Instituto de Ciências Sociais Aplicadas, Redenção / CE - Brazil

This article adopts institutional collective action (ICA) to verify the difference in collective effects when observing inter-municipal cooperation arrangements to provide public health in Brazil (public health consortia). The study compares municipalities that joined consortia in 2009/2010 and municipalities that did not join until 2015. The analysis estimated collective effects of public health consortia and how they relate to contextual variables of policies in this area in the country. The methodology is longitudinal-retrospective deductive research, using the difference-in-differences statistical technique. The results show that municipalities engaged in local inter-municipal cooperation to provide public health in Brazil improved the services in terms of outpatient appointments and the number of primary health care (PHC) consultations, as well as reducing infant deaths.

Keywords: inter-municipal cooperation; institutional collective action; public consortium; health.

\section{Cooperação intermunicipal baseada no Institutional Collective Action: os efeitos dos consórcios públicos de saúde no Brasil}

O objetivo do artigo é verificar a diferença de efeitos coletivos entre os municípios que decidiram aderir a algum consórcio público de saúde em 2009/2010 e os municípios que não aderiram a consórcios públicos até 2015. Utilizou-se o Institutional Collective Action (ICA), para estimar os efeitos coletivos e verificar a sua relação entre variáveis contextuais da política de saúde no Brasil, via consórcios públicos. Trata-se de uma pesquisa dedutiva de tipo longitudinal-retrospectiva, com o uso da técnica estatística denominada "diferenças em diferenças". Os resultados mostram que municípios que participam de consórcio público de saúde no Brasil melhoram a oferta de serviço em número de atendimentos ambulatoriais e número de consultas médicas, além de reduzir o número de óbitos infantis.

Palavras-chave: cooperação intermunicipal; institutional collective action; consórcio público; saúde. 


\section{Cooperación intermunicipal basada en Institutional Collective Action: los efectos de los consorcios de salud pública en Brasil}

El objetivo del artículo es verificar la diferencia en los efectos colectivos entre los municipios que decidieron adherirse a un consorcio de salud pública en 2009/2010 y los municipios que no se adhirieron a los consorcios públicos hasta 2015. Se utilizó la Institutional Collective Action (ICA) para estimar los efectos colectivos y verificar su relación entre variables contextuales de la política de salud en Brasil, a través de consorcios públicos. Se trata de una investigación deductiva longitudinal-retrospectiva, que utiliza la técnica estadística denominada "diferencias en diferencias". Los resultados muestran que los municipios que participan en un consorcio de salud pública en Brasil mejoran la prestación de servicios en términos de número de consultas externas y número de consultas médicas, además de reducir el número de muertes infantiles.

Palabras clave: cooperación intermunicipal; acción colectiva institucional; consorcio público; salud.

\section{ACKNOWLEDGMENTS}

The authors thanks to CNPq financing, process 427712018 4; FUNCAP, process BP4-017200029.01.00/20.

\section{INTRODUCTION}

This article verifies the difference in collective effects between Brazilian municipalities that joined inter-municipal cooperation arrangements to provide public health - public health consortia - in 2009/2010, and the municipalities that did not join until 2015, adopting the institutional collective action (ICA) framework.

Collective action theories have been used extensively to identify drivers for cooperation. Case studies based on such theories analyse the issues related to the actors' context and region in order to understand the emergence of cooperative arrangements (Matos \& Dias, 2012; Meza, Grin, Fernandes \& Abrucio, 2018; Oliveira \& Ganzeli, 2013; Wolfart, Silva \& Schmidt, 2013). The ICA framework (Feiock, 2004, 2007, 2013) assumes that in regions of fragmented governments - multiple governments interacting with each other to provide common public services - local authorities can cooperate, express interests, share resources, and commit to collective action rules in various policy areas.

Studies have examined the effects of inter-municipal cooperation (Bel \& Warner, 2015; Dollery, Grant \& Kortt, 2012; Henderson, 2015; Lago-Penas \& Martinez-Vasquez, 2013; Tomkinson, 2007), particularly in Europe (Henderson, 2015; Hulst \& Monstfort, 2007), North America (Holzer \& Fry, 2011), and Australia (Dollery et al., 2012). However, it is possible to observe numerous studies in other parts of the globe, such as in South Korea (Kim, Andrew \& Jung, 2017), and China (Yi \& Cui, 2018).

In Brazil, inter-municipal cooperation is a strategy used more often in the areas of solid waste and health care. Our choice here to focus on Brazilian health policies consider three characteristics. The first is the design of the country's national health system (SUS), which has allowed, since its very first legislation, the establishment of interlocal cooperation to provide services (Lei no 8.080 , de $19 \mathrm{de}$ setembro de 1990). The second characteristic is the fact that the system's organisational principles lead to creating mechanisms to decentralise and regionalise service provision (Aguiar, 2015; Dourado \& Elias, 2011). And finally, the Law on Public Consortia (Lei no 11.107, de 06 de abril de 2005) which 
establishes that "Public consortia, in the health area, shall comply with the principles, guidelines and norms that regulate the Unified Health System - SUS.

The dissemination of inter-municipal cooperation arrangements in the country is attributed to the Law on Public Consortia, enacted in 2005 (Abrucio \& Sano, 2013). However, it was in 2009 and 2010, according to the National Confederation of Municipalities (Confederação Nacional dos Municípios $[\mathrm{CNM}], 2018)$, that the highest number of municipalities joined these initiatives to provide services in health. Finally, observing the end of 2015 shows the differences between the two groups with enough time for the treatment group to be exposed to the experience of public health consortia.

\section{INSTITUTIONAL COLLECTIVE ACTION}

The environment for cooperation is largely based on the perception of collective gain associated with the interest of public agents. For certain public policies (and collective goods), public agents may seek local partnerships and cooperative agreements inspired by other governments' collective actions that proved to be successful (Kim et al., 2017). Therefore, it is crucial to understand the collective and individual interests involved in cooperation among municipalities to create coordination mechanisms that extend collective actions and measure their effects. The literature indicates that the provision of public services gains effectiveness with knowledge sharing and economies of scale (Bel, Fageda \& Mur, 2014; Bel \& Warner, 2015; Hulst \& Montfort, 2007; Silvestre et al., 2019; Voorn, Genugten \& Thiel, 2019). Research analysing European countries corroborate this finding, demonstrating that inter-municipal cooperation reduces costs based on the economy of scale (Niaounakis \& Blank, 2017).

Several theories address collective action and its dilemmas: overfishing problem (Gordon, 1991); the tragedy of the commons (Hardin, 1968); logic of collective action (Olson, 1971); common-pool resource theory (Ostrom, 1990, 2005, 2011); and institutional collective action (Feiock, 2004, 2007, 2013).

This study focuses on the institutional collective action (ICA) framework (Feiock, 2004, 2007, 2013; Tavares \& Feiock, 2018). This approach assumes that individuals act collectively based on their interests, aiming to obtain benefits at a lower cost than if pursuing the same benefits individually; or to promote political, economic, and social goals and preferences, influenced by contextual and regional aspects.

The intergovernmental approach may be understood as the combination of structural and contextual aspects that drive the operation of government institutions and how government actors relate. Feiock $(2004,2007)$ highlights the importance of interactivity between the actors but adds contextual institutional elements of the region where the collective action takes place. The ICA is comprised of four dimensions: (1) characteristics of communities; (2) structure of policy networks; (3) political institutions; (4) transaction characteristics of goods.

First, the characteristics of communities forge the actors' preferences regarding the collective goods and contribute to identifying the potential gains involved. These characteristics of the context also affect the delivery of public services. They can be demographic and economic (Aly, Reis, Carneiro, \& Moraes, 2017; Bastos, Santos, Costa \& Capilheira, 2011; Oliveira, Freitas, Silva \& Carvalho, 2011; Viacava, Oliveira, Carvalho, Laguardia \& Bellido, 2018), social (Politi, 2014; Thum, Baldisserotto \& Celeste, 2019), and fiscal characteristics (Bel et al., 2014; Hefetz \& Warner, 2011; Lima \& Silveira, 2017; Rossi, Chaves, Almeida, Santos \& Santana, 2018). 
The second element is "the structure of policy networks". The assumption is that, when local authorities engage in several dyadic relations with each other, they constitute, at the macro level, a regional government in the form of a "policy network". Therefore, over time, this regional policy network builds a trustworthy reputation among partners with potential for cooperation (Carr, Hawkins \& Westberg, 2017; Feiock, 2007). The social capital necessary to foster cooperation is created from the strengthening of the bonds among actors, as identified by Percoco (2014). The author studied the case in Italy, showing that a large social capital and a history of collaboration increased the likelihood of a strategic plan for collaboration in Italian municipalities.

The federal and state legislation shape the "characteristics of political institutions", which guide elected officials. These institutions are connected to interlocal cooperation based on their ability to influence decision-making processes. However, actors play a role in creating cooperative alliances with other local governments, differing in their institutional capacity and ability to negotiate (Feiock, Krause \& Hawkins, 2017)

The "transaction characteristics of goods" refers to the characteristics of the services provided through the cooperation arrangement, i.e., the collective goods the individuals pursue. According to Feiock (2007), the particularities of the collective problems influence the way in which actors seek solutions. Thus, public problems with collective solutions and low transaction costs are more likely to be the object of collective agreements. This correlation between transaction costs and the likelihood of collective agreement is inversely corroborated in the study by Johansson, Niklasson and Persson (2015) in Sweden. The authors observed that collective action is rare in an environment of high transaction costs, even though the collective initiative is designed through a bottom-up strategy, i.e., contemplating the interests of all participants and under their leadership.

Among the theories addressing collective action mentioned before, Feiock's (2007) ICA showed to have the key elements to help to explain interlocal cooperation, since the theoretical framework integrates currents of thought from economic sciences, public administration, political science, and social sciences. In addition, the many studies using ICA in Europe (Tavares \& Feiock, 2018; Voorn et al., 2019), China (Yi and Cui 2018), and North America (Feiock et al., 2017), have formed a research agenda based on this framework (Scholz, Feiock \& Ahn, 2006). Finally, studies adopting ICA are still scarce in Brazil, where the work by Fernandes, Pinheiro, Nascimento and Grin (2020) analysing how contextual variables influence local governments' decision to engage in inter-municipal consortia designed to provide waste services in metropolitan regions, stands out.

\section{INTER-MUNICIPAL COOPERATION ARRANGEMENTS - PUBLIC CONSORTIA}

The interdependence among administrative units is one of the main attributes of a federation (Anderson, 2009). The political life in a federation is characterised by the interest of all public agents to influence the outcomes observed in other jurisdictions, which is an element that gains complexity since federated units have administrative autonomy.

Cruz, Araújo and Batista (2012) argue that the cooperation among local, state, and national governments in a given territory is built based on the intergovernmental relations already in place and may contribute to minimising the problems within such relations. This type of cooperation entails strengthening ties among the public agents; knowledge about the common problem, the territory, 
and the regional characteristics; clear notion of the interests involved, and especially, knowledge of the resources available to implement the collective action.

According to Teles (2016 "as cited in Teles \& Swianiewicz, 2018, p. 2), inter-municipal cooperation is amid a critical "paradigm change or [...] territorial instability. It is not just a makeover: it is a profound, yet new, reshaping of structures, institutions, roles, competencies, borders and scale".

In this article, inter-municipal cooperation is understood as a pact among municipalities, made in order to provide public services (Bel \& Warner, 2015; Citroni, Lippi \& Profeti, 2013). Inter-municipal cooperation may vary according to the number of local governments and the type of public service (Blåka, 2017; Citroni et al., 2013). Therefore, regional contextual characteristics may influence the various formats of inter-municipal cooperation.

Intergovernmental cooperation (or public consortia) is a strategy that has gained strength in the face of the "municipal dilemma" when Brazilian federalism grants autonomy to local governments. Municipalities assumed responsibilities regarding the provision of services to meet constitutional obligations, but the design of Brazilian federalism has left local governments with a very low fiscal capacity (Abrucio, Filippim \& Dieguez, 2013; Abrucio, Sano \& Sydow, 2010; Nascimento \& Fernandes, 2015). Brazilian municipalities have low capacity to fund obligations even when considering their entire revenues, formed of locally collected taxes, the distribution of taxes collected at the federal and state levels, and the federal and state transfers received to fund locally implemented social policies as provided in the constitution.

The heterogeneity among municipalities in a vast country such as Brazil results in some local governments facing more financial difficulties than others, revealing different economic, political, and administrative capacities. Studies have demonstrated that municipalities with higher GDP tend to offer better public services (Aly et al., 2017; Bastos et al., 2011; Oliveira et al., 2011; Viacava et al., 2018), and municipalities with high poverty rates face greater difficulties to serve the population. Social problems are different across the country, requiring solutions that vary according to each region and municipality. One of the solutions that has been adopted nationwide is the establishment of inter-municipal cooperation arrangements or public consortia.

A public consortium is an organisational arrangement provided in Brazilian law, by which local, state of federal governments decide to act collectively to solve problems of common interest and in specific territories. These arrangements address problems that would need more resources or could not be solved if a government had to address them alone.

Research by Abrucio and Sano (2013) highlights ten factors that explain the emergence of public consortia in Brazil: active political leadership; fear of the tragedy of the commons; policy design; induction of state and federal governments; initiative from local membership organisations; territorial awareness of the collective action (social capital); previous legacies of cooperation; regional political pacts; activities of civil society organisations; and laws favouring membership organisations and the territory.

In the health area, the institutional design of the SUS induces cooperation through public consortia through inter-federative coordination, potentially contributing to the distribution of collective benefits in a decentralized manner and without compromising the autonomy of entities (Arretche, 2012; Holzinger, 2003). 
The study by Grin and Abrucio (2017) identified that issues such as social inequality and funding significantly influenced the local governments' likelihood to join public health consortia in Brazil in 2011. The authors revealed that the local governments joined such arrangements to reduce costs and gain economies of scale. These results encourage more profound study on the influence of managerial mechanisms in the decision to engage in public health consortia, considering the previous literature and the fact that the design of the Brazilian national health system (SUS) privileges regionalisation of health policies to increase effectiveness.

Grin and Abrucio (2017) synthesise the literature on intermunicipal cooperation/public consortia into four main approaches: 1) Formal (legal, organisational, and managerial); 2) Economic (scale, efficiency, and rationality); 3) Political (intergovernmental coordination and cooperation, responsiveness, and accountability); and 4) Managerial (expansion of management capacity and regional planning).

The study by Grin and Abrucio (2017) identified that issues such as social inequality and funding significantly influenced the local governments' likelihood to join public health consortia in Brazil in 2011. The authors revealed that the local governments joined such arrangements to reduce costs and gain economies of scale. These results encourage more profound study on the influence of managerial mechanisms in the decision to engage in public health consortia, considering the previous literature and the fact that the design of the Brazilian national health system (SUS) privileges regionalisation of health policies to increase effectiveness, efficiency and rationality.

Second Nicoletto, Cordoni and Costa (2004), public consortia have the potential to optimize health services. However, the effects on public health have other intercurrent issues, called Social Determinants of Health - DSS (Organização Mundial de Saúde [OMS], 2008), which are all those social, economic, cultural, ethnic/racial, psychological, and historical conditions that directly or indirectly influence the occurrence of health problems.

For Zioni and Westphal (2007), the level of health results from social stratification, which determines the territorial context, as well as the distribution of essential elements for health: material, biological, psychosocial and behavioral. In other words, socioeconomic inequalities classify the position that the individual occupies in social stratification and determines the access to factors of good or bad health, leading to an increase in health inequities.

In this sense, the model by Dahlgren and Whitehead (2007) was proposed to estimate the DSS from the most individual to the most comprehensive scope, called macrodeterminants. And the latter are used in this research, especially regarding the dimensions: demographic, economic and social.

\section{METHODOLOGY}

The study adopts a deductive-inductive, observational, and longitudinal-retrospective approach, analysing treatment and control groups (Dahlgren \& Whitehead, 2007), to compare municipalities that joined public health consortia (treatment group) and municipalities that did not join these arrangements (control group).

The difference-in-differences (DID) technique was used for statistical estimation, comparing the effects in both groups. According to Peixoto, Foguel, Pinto, Lima and Barros (2016), DID is a quasi-experimental technique. The researchers' activity is limited to collecting the data affected by 
exogenous forces (economic, political, social, or natural), i.e., the researchers do not interfere in the treatment of individuals.

DID consists of a double subtraction, as shown in Box 1:

BOX 1

DIFFERENCES IN DIFFERENCES - MATHEMATICAL REPRESENTATION

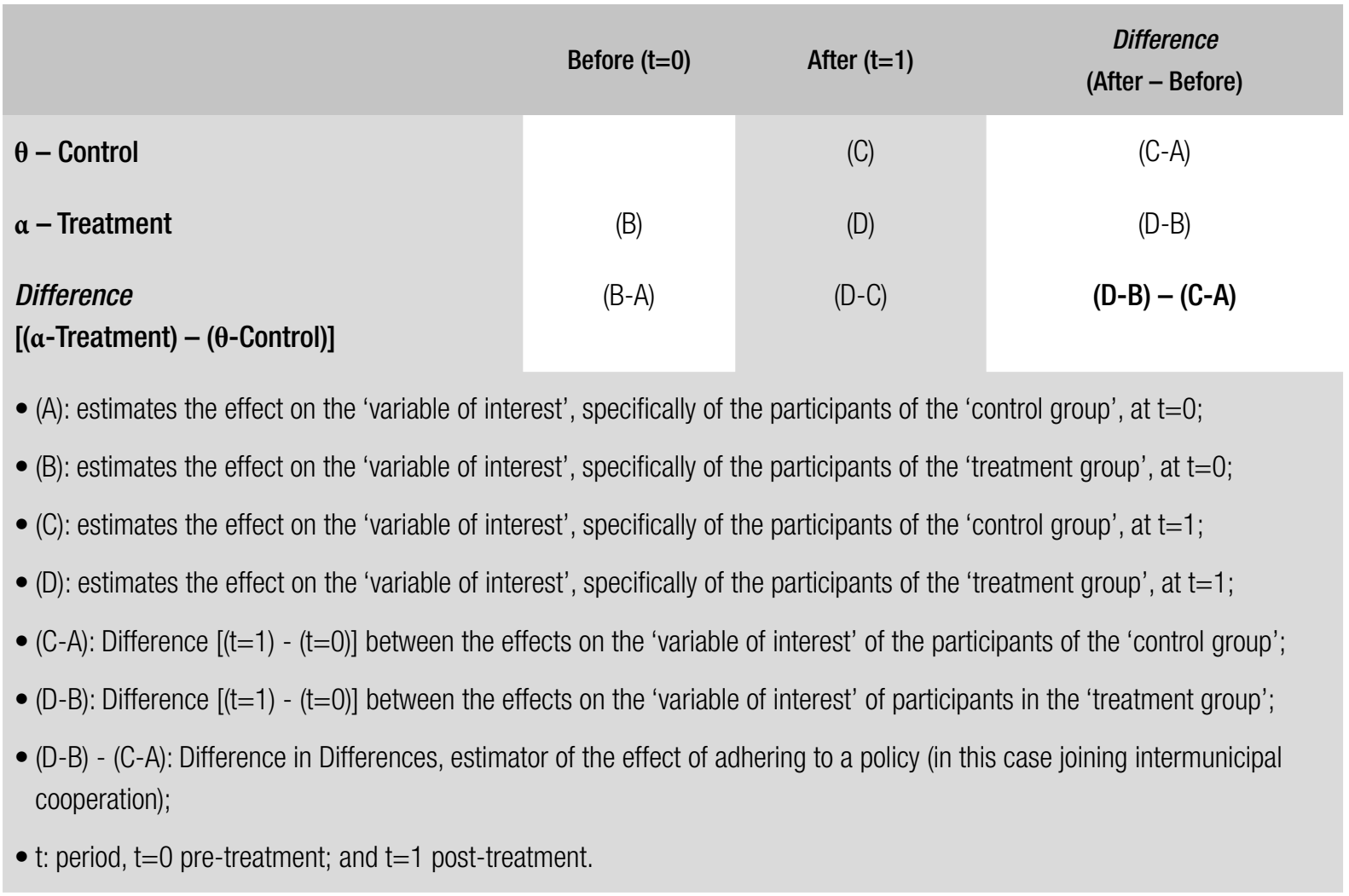

Source: Research data collected in 2019.

The reason for selecting municipalities that joined public health consortia in 2009 and 2010 is because most local governments that engaged in intermunicipal cooperation after the enactment of the Public Consortia Law (Lei no 11.107, de 06 de abril de 2005) did so in this period (433 municipalities joined at least one public health consortium). Therefore, the period of analysis starts in 2005 (when none of the municipalities of the sample were involved in health policy consortia) and ends in 2015 (when some of the municipalities of the sample, at the treatment moment, had joined public health consortia) (Figure 1). 


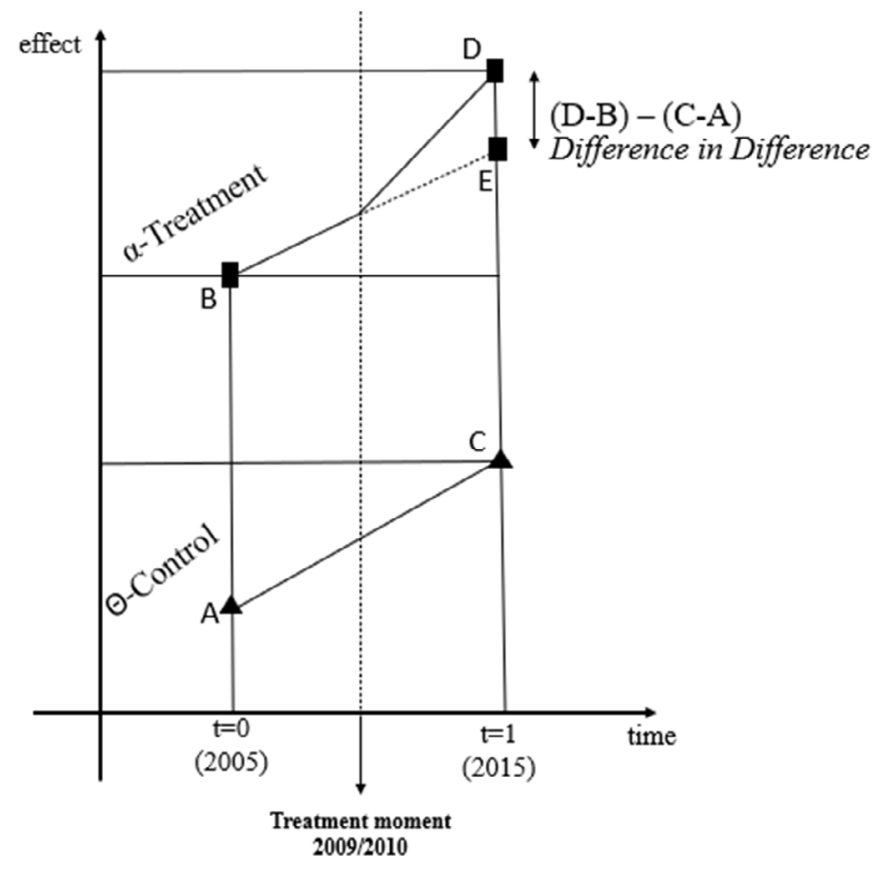

Source: Elaborated by the authors.

The universe of the research comprises all municipalities that joined at least one public health consortium in 2009/2010 ( $\mathrm{n}=433$ municipalities) added to all municipalities that had not joined any public health consortium until 2015 ( $\mathrm{n}=2,271$ municipalities), totalling 2,704 municipalities. To obtain homogeneity of the analysed data, we excluded the municipalities a) with missing information in the CNM database; $b$ ) that appeared engaged in public health consortia but, according to a survey of the CNM (2018), the consortia were not active; and c) municipalities that declared to be in a consortium, but in an administrative type consortium. After this exclusion and using the propensity match score technique, the sample resulted in 1138 municipalities, 276 in the treatment group and 862 in the control group.

With the software Stata/ $\mathrm{MP}^{\circledast}$ version 14.0 we tested the assumptions of multiple regression, which were: normality (Shapiro-Wilk test, the null hypothesis is the normal distribution, p-value $<0.10$ ); homoscedasticity (Breusch-Pagan test, the null hypothesis is the presence of heteroscedasticity, p-value $<0.10$ ); no perfect collinearity (VIF test, tolerance below 10.0); and independence of error term (Durbin-Watson test, the null hypothesis is the presence of autocorrelation of the error term, p-value $<0.05$, the result should be approximately equal to 2) (Fávero, 2015; Hair, Black, Babin, Anderson \& Tatham, 2009; Wooldridge, 2012).

The data were organised in a short-balanced panel of two periods (2005 and 2015). With these data, clustering of regressions for each dependent variable was generated, each with three models, explained below. We used the regression for panel data with random effects, which is recommended when the variation in time between individuals is considered random, therefore, preserving the differences between them (Fávero, 2015). 
The regression with random effects showed heteroscedasticity, i.e., not constant variation in terms of errors, so we used the method of generalised least squares (GLS). Thus, maintaining the variances of the effects between municipalities, the mathematical expression for this modelling is:

$$
\mathrm{Y}_{\mathrm{it}}=\beta_{1} \mathrm{X}_{1 \mathrm{it}}+\beta_{2} \mathrm{X}_{2 \mathrm{it}}+\beta \alpha \mathrm{D}_{\mathrm{it}-1} \ldots \beta_{\mathrm{k}} \mathrm{X}_{\mathrm{kit}}+\left(\alpha_{\mathrm{i}}+\varepsilon_{\mathrm{it}}\right)
$$

Where:

$\mathrm{Y}=$ dependent variable (answer)

$\beta=$ parameter of coefficient

$\mathrm{X}=$ independent variable (explanatory)

$\mathrm{D}=$ dummy DID (pre-treatment - post-treatment)

$\mathrm{k}=$ index of variables

$\alpha=$ behaviour of individual effects

$\varepsilon=$ (Robust) error term

$\mathrm{i}=$ index of municipalities

$\mathrm{t}=$ period of data collection

After performing the regressions, the interpretations followed the ' $\mathrm{t}$ ' statistic tests, indicated by Fávero (2015), Hair et. al. (2009), and Wooldridge (2012), which checks the significance of each parameter of the regression model. The $t$-test hypotheses for the intercept $(\beta 0)$ are $(\mathrm{H} 0: \beta 0=0 ; \mathrm{H1}: \beta 0 \neq 0)$; and for the parameters $(\beta \mathrm{k})(\mathrm{H0}: \beta \mathrm{k}=0 ; \mathrm{H1}: \beta \mathrm{k} \neq 0)$. These are significant when the $\mathrm{P}$-value $<0.05$.

The study used the following databases: Brazilian Institute of Geography and Statistics (Instituto Brasileiro de Geografia e Estatísticas, 2019a, 2019b); National Treasury Secretariat (Secretaria do Tesouro Nacional, 2019); National Confederation of Municipalities (Confederação Nacional dos Municípios, 2018); Department of Informatics of the Single Health System DataSUS (Departamento de Informática do Sistema Único de Saúde DataSUS, 2019); and the Superior Electoral Court (Tribunal Superior Eleitoral, 2019). Box 2 below presents the description of the variables:

\begin{tabular}{|c|c|c|c|c|}
\hline \multicolumn{5}{|l|}{ Dependent variables } \\
\hline \multirow{3}{*}{$\begin{array}{l}\text { Characterisics of the goods } \\
\text { (Feiock, 2004, 2007, 2013) }\end{array}$} & outpatient & $\begin{array}{l}\text { Total outpatient appointments (based } \\
\text { on patient's place of residence) }{ }^{<?>}\end{array}$ & DataSus & $2004 / 2014$ \\
\hline & consultation & $\begin{array}{l}\text { Total primary health care (PHC) } \\
\text { consultation in } \mathrm{PHC} \text { facilities }\end{array}$ & DataSUS & $2004 / 2014$ \\
\hline & infant_death & $\begin{array}{l}\text { Total infant death (based on family's } \\
\text { place of residence) }\end{array}$ & DataSUS & $2004 / 2014$ \\
\hline \multicolumn{5}{|l|}{ Independent variables } \\
\hline Diff-in-Diff & DID & Estimator of difference-in-differences & & $2004 / 2014$ \\
\hline
\end{tabular}


RAP | Inter-municipal cooperation based on Institutional Collective Action: the effects of public health consortia in Brazil

\begin{tabular}{|c|c|c|c|c|}
\hline $\begin{array}{l}\text { Demographic } \\
\text { characteristics (Feiock, } \\
2004,2007,2013 \text { ) }\end{array}$ & $\mathrm{PD} / \mathrm{km}^{2}$ & $\begin{array}{l}\text { Number of inhabitants } \\
\text { Population density, calculated by the } \\
\text { number of inhabitants per square } \\
\text { kilometer }\left(\mathrm{km}^{2}\right)\end{array}$ & IBGE & $2004 / 2014$ \\
\hline \multirow{3}{*}{$\begin{array}{l}\text { Economic characteristics }{ }^{<?>} \\
\text { (Feiock, 2004, 2007, 2013) }\end{array}$} & cap_GDP & Total GDP per number of inhabitants & IBGE & $2004 / 2014$ \\
\hline & GDP & Gross Domestic Product (GDP) & STN & $2004 / 2014$ \\
\hline & \%poverty & $\begin{array}{l}\text { Proportion of individuals with a } \\
\text { household income equal or inferior to } \\
R \$ 140,00 \text { per capita per month in } \\
\text { August } 2010 \text {. }\end{array}$ & PNUD <?> & $2000 / 2010$ \\
\hline \multirow{3}{*}{$\begin{array}{l}\text { Social characteristics } \\
\text { (Feiock, 2004, 2007, 2013) }\end{array}$} & unemployed & $\begin{array}{l}\text { Percentage of unemployed labor } \\
\text { force }\end{array}$ & PNUD & $2000 / 2010$ \\
\hline & sanitation & $\begin{array}{l}\text { Number of households with basic } \\
\text { sanitation }\end{array}$ & DataSus & $2004 / 2014$ \\
\hline & fin_depend_ & $\begin{array}{l}\text { Total intergovernmental transfers } \\
\text { divided by total current revenues }\end{array}$ & STN & $2004 / 2014$ \\
\hline \multirow{3}{*}{$\begin{array}{l}\text { Fiscal characteristics }{ }^{<?>} \\
\text { (Bel \& Warner 2015; } \\
\text { Feiock, 2004, 2007, 2013) }\end{array}$} & \$cap_health & Health expenditure per capita & STN & $2004 / 2014$ \\
\hline & $\operatorname{tax}$ & $\begin{array}{l}\text { Total tax revenues per total current } \\
\text { revenues }\end{array}$ & STN & $2004 / 2014$ \\
\hline & pub_debt & $\begin{array}{l}\text { Total current expenditures per total } \\
\text { current revenues }\end{array}$ & STN & $2004 / 2014$ \\
\hline \multirow[t]{3}{*}{$\begin{array}{l}\text { Structure of political } \\
\text { networks } \\
\text { (Feiock, 2004, 2007, 2013) }\end{array}$} & other_consor & $\begin{array}{l}\text { Whether the municipality joined other } \\
\text { type of public consortia (Yes=1; } \\
\mathrm{No}=0 \text { ) }\end{array}$ & CNM & $2004 / 2014$ \\
\hline & Civil servant & $\begin{array}{l}\text { Number of civil servants (in the direct } \\
\text { public administration) with higher } \\
\text { education }\end{array}$ & IBGE & $2004 / 2014$ \\
\hline & re-election & $\begin{array}{l}\text { Whether the local executive authority } \\
\text { was re-elected in the previous } \\
\text { election (Yes=1; No=0) }\end{array}$ & TSE & $\begin{array}{l}2000 / 2004 \\
-2008 / 2012\end{array}$ \\
\hline
\end{tabular}

Source: Research data collected in 2019.

For 2005 all municipalities were codified with $\mathrm{DID}=0$, since none of them participated in a public health consortium. For 2015 the treatment group municipalities were codified with $\mathrm{DID}=1$, since they joined at least one public health consortium in 2009/2010.

The general hypothesis is: contextual characteristics of municipalities contribute to explain the collective effects of health policy. These characteristics influence differently the indicators of health service provision and infant death in municipalities that join public health consortia in comparison to municipalities that do not (Feiock, 2004, 2007, 2013). 
We prepared a regression table for each dependent variable, and three models were tested in each table: (1) In the first model all independent variables were included; (2) the second maintained demographic, economic, and social variables; (3) and the third maintained demographic, economic, fiscal, political, and institutional variables, allowing to test the results of fiscal stress variables and other ICA groups ('structure of policy network' and 'political institutions').

\section{RESULTS AND DISCUSSION}

In the first dependent variable (outpatient) the results were significant only in model 03, which excluded the social variables from the model. The demographic and economic characteristics corroborate the positions of ICA by highlighting the importance of contextual characteristics in the decision to cooperate. Fiscal and structural characteristics were also included in this model, contributing to explain the influence of the health consortium in the number of outpatient services (Table 1):

\section{TABLE 1 REGRESSION - NUMBER OF OUTPATIENT APPOINTMENTS - 2005/2015}

\begin{tabular}{|c|c|c|c|c|}
\hline Group & VAR & $\begin{array}{c}\text { (1) } \\
\text { outpatient }\end{array}$ & $\begin{array}{c}\text { (2) } \\
\text { outpatient }\end{array}$ & $\begin{array}{c}\text { (3) } \\
\text { outpatient }\end{array}$ \\
\hline \multirow[t]{4}{*}{ Differences in Differences } & DID & 79892,386 & 68455,274 & $134813,965^{\star \star}$ \\
\hline & & $(57401,891)$ & $(56643,504)$ & $(64040,772)$ \\
\hline & pop & $3,492^{\star \star}$ & $3,604^{\star \star *}$ & $3,484^{\star \star}$ \\
\hline & & $(1,422)$ & $(1,327)$ & $(1,367)$ \\
\hline \multirow{4}{*}{ Demographic characteristics } & $\mathrm{PD} / \mathrm{km}^{2}$ & $975,674^{*}$ & $1098,273^{\star *}$ & $973,762^{*}$ \\
\hline & & $(536,160)$ & $(522,613)$ & $(533,634)$ \\
\hline & cap_GDP & $-15659,366^{\star \star}$ & $-14186,728 *$ & $-10856,764^{*}$ \\
\hline & & $(7848,367)$ & $(8109,996)$ & $(6550,369)$ \\
\hline \multirow{5}{*}{ Economic characteristics } & GDP & $0,406^{\star \star \star}$ & $0,408^{\star \star \star}$ & $0,402^{\star \star \star}$ \\
\hline & & $(0,020)$ & $(0,019)$ & $(0,019)$ \\
\hline & \%poverty & $-6733,788^{\star \star *}$ & $-9927,631^{\star \star *}$ & \\
\hline & & $(2418,627)$ & $(2805,055)$ & \\
\hline & unemployed & 1686,876 & 2897,844 & \\
\hline \multirow{3}{*}{ Social characteristics } & & $(2044,886)$ & $(2219,640)$ & \\
\hline & sanitation & $-1,732$ & 0,957 & \\
\hline & & $(7,292)$ & $(6,110)$ & \\
\hline
\end{tabular}




\begin{tabular}{|c|c|c|c|c|}
\hline Group & VAR & $\begin{array}{c}\text { (1) } \\
\text { outpatient }\end{array}$ & $\begin{array}{c}\text { (2) } \\
\text { outpatient }\end{array}$ & $\begin{array}{c}\text { (3) } \\
\text { outpatient }\end{array}$ \\
\hline \multirow{7}{*}{ Fiscal characteristics } & fin_depend_ & $-782851,911$ & & $-100062,333$ \\
\hline & & $(601707,771)$ & & $(647359,490)$ \\
\hline & \$cap_health & 0,003 & & 0,003 \\
\hline & & $(0,006)$ & & $(0,005)$ \\
\hline & $\operatorname{tax}$ & 1124318,137 & & 1626147,344 \\
\hline & & $(1079771,981)$ & & $(1078661,764)$ \\
\hline & pub_debt & $-260745,702$ & & $-438736,677^{\star \star}$ \\
\hline \multirow{3}{*}{$\begin{array}{c}\text { Structure of political } \\
\text { networks }\end{array}$} & & $(179936,126)$ & & $(200745,688)$ \\
\hline & other_consor & $-83903,099$ & & $-77012,371$ \\
\hline & & $(82540,917)$ & & $(82545,612)$ \\
\hline \multirow{9}{*}{ Political institutions } & civil servants & $-1,331$ & & 4,910 \\
\hline & & $(101,833)$ & & $(101,717)$ \\
\hline & re-election & $-8520,258$ & & $-10003,042$ \\
\hline & & $(26335,524)$ & & $(26779,556)$ \\
\hline & Constant & $1471713,652^{*}$ & $723589,389^{\star \star \star}$ & $1401301,836^{*}$ \\
\hline & & $(775155,250)$ & $(243065,339)$ & $(732011,248)$ \\
\hline & Obs & 1138 & 1138 & 1138 \\
\hline & $\mathrm{R}^{2}$ & 0,966 & 0,965 & 0,966 \\
\hline & Wald chi² & $5838,91^{\star \star \star}$ & $5953,05^{\star \star \star}$ & $3323,12^{\star \star \star}$ \\
\hline
\end{tabular}

Note: Robust standard errors in brackets $\left[{ }^{* * *} \mathrm{p}<0.01,{ }^{* *} \mathrm{p}<0.05,{ }^{*} \mathrm{p}<0.10\right]$ Source: Research data collected in 2019 .

These results show that factors foreseen in the ICA influence the effects of collective benefit and support the argument that contextual aspects of fragmented governments influence the number of outpatient appointments. Above all, the results validate the hypothesis that public health consortia increase outpatient service in comparison to municipalities that did not join one.

This finding corroborates the study by Kim et al. (2017), who analysed the supply of health services through collaboration among governments in South Korea. The authors suggested that strengthening communication among governments that cooperate in providing public health policy results in better services.

Ceteris paribus, an increase in population and Gross Domestic Product (GDP) have a positive influence on the number of outpatient appointments, which was also observed in previous literature (Aly et al., 2017; Bastos et al., 2011; Oliveira et al., 2011; Viacava et al., 2018). On the other hand, the variable GDP per capita behaves oppositely to the number of outpatient appointments, leading to the conclusion that smaller municipalities with high GDP are more likely to fail in providing 
outpatient services.

As for social characteristics, only the variable '\%poverty' reduces the number of outpatient appointments, and this corroborates the theoretical propositions of Politi (2014) when the author argues that regions with higher rates of poverty are also those with greater difficulties of access to health services and other essential public services.

Among the fiscal characteristics, the variable 'pub_debt' indicated that indebted municipalities present a lower number of outpatient appointments, i.e., the increase in new services may be negatively affected by the indebtedness of local governments (Lima \& Silveira, 2017; Rossi et al., 2018).

In Hefetz and Warner's (2011) research, corroborated by Bel et al. (2014), fiscal stress is a community characteristic that hinders collective gains in cooperation. This condition challenges the municipalities ability to obtain new resources and establish partnerships, forcing managers to set fiscal priorities that may compromise essential areas such as health. Moreover, when considering the responsibilities of municipalities participating in arrangements as provided in Brazilian law on public consortia, those with debt problems may have difficulties to honour their financial obligations. Therefore, the negative significance corroborates the literature.

In the regression with the number of PHC consultations (consult), the difference-in-differences was significant in all models. Therefore, municipalities that joined public health consortia increased the number of PHC consultations (Table 2).

TABLE 2 REGRESSION - NUMBER OF PRIMARY HEALTH CARE CONSULTATIONS - 2005 AND 2015

\begin{tabular}{|c|c|c|c|c|}
\hline Group & VAR & $\begin{array}{c}\text { (1) } \\
\text { consultation }\end{array}$ & $\begin{array}{c}\text { (2) } \\
\text { consultation }\end{array}$ & $\begin{array}{c}\text { (3) } \\
\text { consultation }\end{array}$ \\
\hline Differences in Differences & DID & $\begin{array}{l}8470,550^{* *} \\
(3535,982)\end{array}$ & $\begin{array}{l}6429,556^{\star} \\
(3363,054)\end{array}$ & $\begin{array}{l}8364,630^{* *} \\
(4120,295)\end{array}$ \\
\hline Dom & pop & $\begin{array}{l}0,061^{*} \\
(0,032)\end{array}$ & $\begin{array}{l}0,038 * \\
(0,023)\end{array}$ & $\begin{array}{c}0,062 \\
(0,038)\end{array}$ \\
\hline Demograpmic Cilaractenstics & $\mathrm{PD} / \mathrm{km}^{2}$ & $\begin{array}{c}26,056^{\star \star \star} \\
(9,636)\end{array}$ & $\begin{array}{c}27,740^{\star \star \star} \\
(9,640)\end{array}$ & $\begin{array}{c}27,499^{\star \star *} \\
(10,520)\end{array}$ \\
\hline \multirow{2}{*}{ Economic characteristics } & cap_GDP & $\begin{array}{c}-48,679 \\
(108,341)\end{array}$ & $\begin{array}{c}-70,759 \\
(127,731)\end{array}$ & $\begin{array}{l}-171,632 \\
(153,448)\end{array}$ \\
\hline & GDP & $\begin{array}{c}0,003^{\star \star \star} \\
(0,001)\end{array}$ & $\begin{array}{l}0,003^{\star *} \\
(0,001)\end{array}$ & $\begin{array}{c}0,005^{\star \star \star} \\
(0,001)\end{array}$ \\
\hline
\end{tabular}


RAP | Inter-municipal cooperation based on Institutional Collective Action: the effects of public health consortia in Brazil

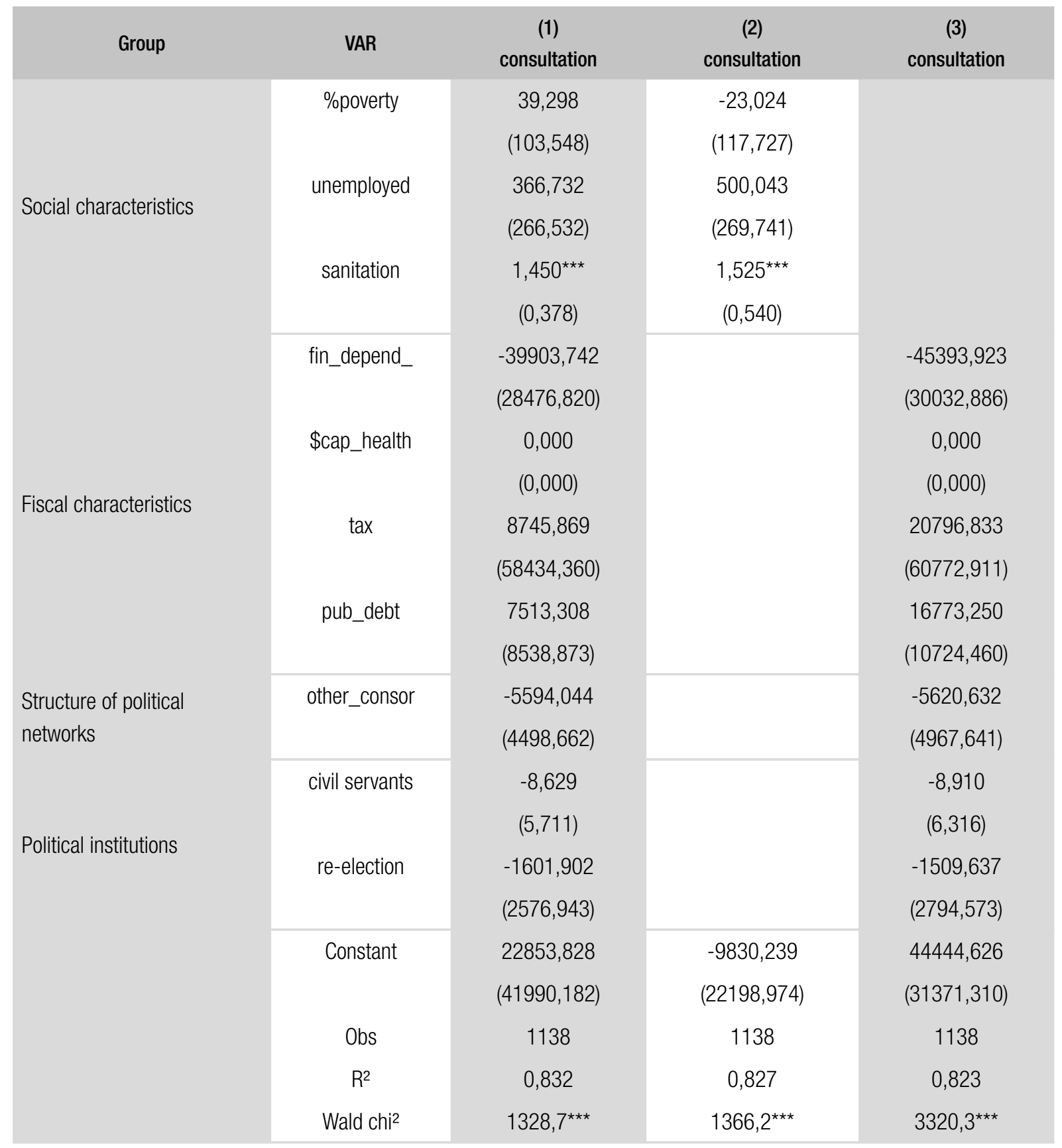

Note: Robust standard errors in brackets $\left[{ }^{* * *} \mathrm{p}<0.01,{ }^{* *} \mathrm{p}<0.05,{ }^{\star} \mathrm{p}<0.10\right]$

Source: Research data collected in 2019. 
The results infer that municipalities that joined public health consortia in 2009/2010 increased the number of PHC consultations significantly compared to municipalities that did not join one. This confirms Grin and Abrucio (2017) argument that 'economies of scale' is one of the factors that explain the engagement in inter-municipal cooperation arrangements. This result contributes to confirming the hypothesis, allowing to say that public health consortia tend to improve PHC and outpatient services.

These findings confirm the conclusions of Nicoletto et al. (2004), who demonstrated that intermunicipal cooperation expanded the capacity to offer specialised medical consultations in the Brazilian state of Paraná. They also corroborate the literature on collective action in regions of fragmented governments and contradicts the economic and 'non-contextual' arguments predicting the occurrence of selfish use of finite collective goods in cooperative environments. On the contrary, collective effects may be encouraged by increased public service provision.

As for the demographic characteristics in Table 2, this research corroborates a study by Thum et al. (2019). The authors observed the influence of these characteristics on the prevalence of medical consultations. They noted that this relationship varies according to the singularities of the country analysed. In Brazil, Boing, Matos, Arruda, Oliveira and Njaine (2010) identified inequities among the economically underprivileged population. Even with greater frequency of diseases, and therefore the need for more services, they are the stratum of the population that is least able to get medical consultations.

The variable measuring the number of households with sanitation suggests that municipalities with more homes with adequate sanitation have higher numbers of medical consultations. However, this indicator may seem paradoxical at first glance, since municipalities with better sanitation structures also have better health structures and, therefore, offer more public services, as opposed to the results of Siqueira, Rosa, Bordin and Nugem (2017).

As for infant deaths, the data show that the municipalities in a public health consortium achieved a significantly higher reduction in the number of child deaths than the municipalities in the control group, contributing to confirm the research hypothesis. The effects of joining public health consortia not only affected the delivery of services but also improved indicators used to evaluate health policy (Table 3). 


\section{TABLE 3 REGRESSION MODEL - INFANT DEATHS - 2005 AND 2015}

\begin{tabular}{|c|c|c|c|c|}
\hline Group & VAR & $\begin{array}{c}\text { (1) } \\
\text { infant_death }\end{array}$ & $\begin{array}{c}\text { (2) } \\
\text { infant_death }\end{array}$ & $\begin{array}{c}\text { (3) } \\
\text { infant_death }\end{array}$ \\
\hline \multirow[t]{2}{*}{ Differences in Differences } & DID & $\begin{array}{c}-1,709^{\star \star} \\
(0,847)\end{array}$ & $\begin{array}{l}-1,399 \\
(0,899)\end{array}$ & $\begin{array}{c}-2,124^{\star \star *} \\
(0,804)\end{array}$ \\
\hline & pop & $\begin{array}{c}21,068^{* \star *} \\
(3,535)\end{array}$ & $\begin{array}{c}22,143^{\star \star *} \\
(4,226)\end{array}$ & $\begin{array}{c}22,456^{\star \star *} \\
(3,586)\end{array}$ \\
\hline \multirow{3}{*}{ Demographic characteristics } & $\mathrm{PD} / \mathrm{km}^{2}$ & $0,063^{\star \star}$ & $0,071^{\star \star}$ & $0,064^{\star \star}$ \\
\hline & & $(0,026)$ & $(0,033)$ & $(0,028)$ \\
\hline & cap_GDP & $-0,290$ & $-0,279$ & $-0,271$ \\
\hline \multirow[t]{2}{*}{ Economic characteristics } & GDP & $\begin{array}{l}(0,212) \\
-2,397^{\star} \\
(1,456)\end{array}$ & $\begin{array}{c}(0,183) \\
-2,574^{\star \star} \\
(1,223)\end{array}$ & $\begin{array}{c}(0,189) \\
-3,301^{\star \star \star} \\
(1,062)\end{array}$ \\
\hline & \%poverty & $\begin{array}{l}0,088 \\
(0,056)\end{array}$ & $\begin{array}{l}0,068 \\
(0,056)\end{array}$ & \\
\hline \multirow[t]{3}{*}{ Social characteristics } & unemployed & $\begin{array}{l}0,071 \\
(0,048)\end{array}$ & $\begin{array}{l}0,053 \\
(0,046)\end{array}$ & \\
\hline & sanitation & $\begin{array}{l}-0,000 \\
(0,000)\end{array}$ & $\begin{array}{l}-0,000 \\
(0,000)\end{array}$ & \\
\hline & fin_depend_ & $\begin{array}{c}4,827 \\
(16,179)\end{array}$ & & $\begin{array}{c}7,034 \\
(16,362)\end{array}$ \\
\hline \multirow{3}{*}{ Fiscal characteristics } & \$cap_health & $\begin{array}{l}-0,000 \\
(0,000)\end{array}$ & & $\begin{array}{l}-0,000 \\
(0,000)\end{array}$ \\
\hline & $\operatorname{tax}$ & $\begin{array}{c}10,580 \\
(29,259)\end{array}$ & & $\begin{array}{c}10,352 \\
(31,156)\end{array}$ \\
\hline & pub_debt & $\begin{array}{c}11,840^{\star *} \\
(5,285)\end{array}$ & & $\begin{array}{c}10,576^{\star \star \star} \\
(4,079)\end{array}$ \\
\hline Structure of political networks & other_consor & $\begin{array}{c}1,508 \\
(2,184)\end{array}$ & & $\begin{array}{l}1,265 \\
(2,096)\end{array}$ \\
\hline \multirow{6}{*}{ Political institutions } & civil servants & $\begin{array}{c}0,015 \\
(0,009)\end{array}$ & & $\begin{array}{l}0,014 \\
(0,007)\end{array}$ \\
\hline & re-election & $\begin{array}{l}-0,993 \\
(0,859)\end{array}$ & & $\begin{array}{l}-0,908 \\
(0,781)\end{array}$ \\
\hline & Constant & $\begin{array}{c}-196,360^{\star \star \star} \\
(38,949)\end{array}$ & $\begin{array}{c}-186,386^{\star \star \star} \\
(35,864)\end{array}$ & $\begin{array}{c}-189,957^{\star \star \star} \\
(40,843)\end{array}$ \\
\hline & Obs & 1.138 & 1.138 & 1.138 \\
\hline & $\mathrm{R}^{2}$ & 0,575 & 0,404 & 0,567 \\
\hline & Wald chi² & $291,60^{\star \star \star}$ & $144,78^{\star \star \star}$ & $210,21^{\star \star \star}$ \\
\hline
\end{tabular}

Note: Robust standard errors in brackets $\left[{ }^{* *} \mathrm{p}<0.01,{ }^{\star *} \mathrm{p}<0.05,{ }^{\star} \mathrm{p}<0.10\right]$

Source: Research data collected in 2019. 
A practical implication aligned with the results of this research can be observed in the studies by Niaounakis and Blank (2017). They affirm that supplying services in larger scale through cooperation results in cost reduction depending on factors such as the total cost to offer the service, the intensity of work, degree of the service complexity, and the level of standardisation required.

The reduction in infant deaths in the municipalities of the treatment group demonstrates that the expansion in health service provision is related to improving the population's health quality.

The population (pop) variable denotes that municipalities with larger population tend to have a higher number of infant deaths. This number, however, may be explained by 'reverse causality' (Fávero, 2015; Hair et al., 2009) since the number of infant deaths is naturally greater in municipalities with larger populations. This rationale may apply to the variable of demographic density.

The results indicate that the increase in GDP reduces the number of infant deaths, corroborating the research by Lourenço et al. (2014), which identified a negative relationship between socioeconomic and demographic variables and infant mortality rates in the state of São Paulo.

The indebtedness rate presented positive significance in two models ( 1 and 3 ). That is, among the observed municipalities, the analysis of 2005 and 2015 indicated that the higher the indebtedness rate, the higher the infant death rates. Although we cannot attribute a causal relationship, it is possible to infer that there are 'behaviours' of positive trends between these two variables. That is, municipalities that have tax debt have higher infant death rate. This situation confirms the relationship between fiscal stress and worse public service delivery (Bel et al., 2014; Hefetz \& Warner, 2011).

\section{FINAL CONSIDERATIONS}

Inter-municipal cooperation in a federation is a complex issue due to the multiplicity of interests among the government instances. Estimating the effects of a policy implemented in these contexts is challenging and at the same time urgent in the face of the recent practices of intergovernmental partnerships in contexts presenting increasingly common problems.

Demographic, economic, and fiscal characteristics have influenced the results of outpatient service provision, suggesting that these contextual factors of the ICA are also important to observe the effects of health policy. Therefore, municipalities that joined public health consortia in 2009/2010 increased the supply of public health services when observing the years 2005 to 2015.

Therefore, the factors in the ICA framework - characteristics of communities, the structure of policy networks, political institutions, and transaction characteristics of goods - are relevant to observe the collective effects of governments in fragmented environments, as well as to explain the effects of the policy in the municipality, as demonstrated in this research.

This study shows that the collective gains of inter-municipal cooperation in Brazil validate the assumptions of the literature on collective action. Therefore, the results are sufficient to encourage the formulation of public policies to promote inter-municipal cooperation. 
RAP | Inter-municipal cooperation based on Institutional Collective Action: the effects of public health consortia in Brazil

Finally, future research could perform cluster efficiency tests in specific consortia, assessing more accurately the effects of health policies in the regions served by these arrangements and their contextual characteristics. Limitations of this research include the absence of annual municipal data that would allow regressions with long panel data or a difference-in-differences with multiple periods. In addition, other epidemiological variables that characterize the profile of municipal public health, not included because it is not the focus of the ICA model, can influence the model's results. 


\section{REFERENCES}

Abrucio, F. L., Filippim, E. S., \& Dieguez, R. C. (2013). Innovation in inter-municipal cooperation in Brazil: the experience of Federação Catarinense de Municípios (Fecam) in the construction of public consortia. Revista de Administração Pública, 47(6), 1543-1568. Retrieved from https://doi.org/10.1590/ S0034-76122013000600010

Abrucio, F. L., \& Sano, H. (2013). Associativismo intergovernamental: experiências brasileiras. Brasília, DF: Editora IABS.

Abrucio, F. L., Sano, H., \& Sydow, C. (2010). Radiografia do associativismo territorial brasileiro: tendências, desafios e impactos sobre as regiões metropolitanas. In F. Magalhães (Ed.), Regiões metropolitanas no Brasil (pp. 197-234). Washington, DC: BID

Aguiar, Z. N. (2015). SUS-Sistema Único de Saúde: antecedentes, percurso, perspectivas e desafios. São Paulo, SP: Editora Martinari.

Aly, C. M. C., Reis, A. T., Carneiro, S. A. M., \& Moraes, F. S. (2017). The Unified Health System in a historical series of indicators: a national perspective for action. Saúde Debate 41(113), 500-512. Retrieved from https://doi.org/10.1590/0103-1104201711312

Anderson, G. (2009). Federalismo: uma introdução. Rio de Janeiro, RJ: FGV IDESP.

Arretche, M. (2012). As relações verticais na federação: explorando o problema da descentralização e da autonomia. In M. Arretche (Ed.), A Democracia, federalismo e centralização no Brasil (pp. 145-173). Rio de Janeiro, RJ: FGV.

Bastos, G. A. N., Santos, I. S., Costa, J. S. D., \& Capilheira, M. F. (2011). Ambulatory care utilization in the past 15 years: Comparison between two population-based studies. Revista Brasileira de Epidemiologia 14(4), 620-32. Retrieved from https:// doi.org/10.1590/S1415-790X2011000400009

Bel, G., Fageda, X., \& Mur, M. (2014). Does cooperation reduce service delivery costs? Evidence from residential solid waste services. Journal of Public Administration Research and Theory, 24(1), 85-107. Retrieved from https://doi.org/10.1002/ pam.20509

Bel, G., \& Warner, M. E. (2015). Factors explaining inter-municipal cooperation in service delivery: a meta-regression analysis. Journal of Economic Policy Reform, 19(2), 91-115. Retrieved from https://doi.or g/10.1080/17487870.2015.1100084

Blåka, S. (2017). Does cooperation affect service delivery costs? Evidence from fire services in norway. Public Administration, 95(4), 1092-1106. Retrieved from https://doi.org/10.1111/padm.12356

Boing, A. F., Matos, I. B., Arruda, M. P., Oliveira, M. C., \& Njaine, K. (2010). Prevalence of medical visits and associated factors: a population-based study in Southern Brazil. Revista Associação Médida Brasileira, 56(1), 41-46. Retrieved from https://doi. org/10.1590/S0104-42302010000100014

Carr, J. B., Hawkins, C. V., \& Westberg, D. E. (2017). An exploration of collaboration risk in joint ventures: perceptions of risk by local economic development officials. Economic Development Quarterly, 31(3), 210-227. Retrieved from https:// doi.org/10.1177/0891242417710325

Citroni, G., Lippi, A., \& Profeti, S. (2013). Remapping the state: inter-municipal cooperation through corporatisation and public-private governance structures. Local Government Studies, 39(2), 208234. Retrieved from https://doi.org/10.1080/03003 930.2012.707615

Confederação Nacional dos Municípios. (2018). Mapeamento dos consórcios públicos brasileiros. Brasília, DF: Author.

Cruz, M. C. M. T., Araújo, F. F., \& Batista, S. (2012). Consórcios numa perspectiva histórico-institucional. Rio de Janeiro, RJ: Fundação Konrad Adenauer.

Dahlgren, G., \& Whitehead, M. (2007). Policies and strategies to promote social equity in health background document to WHO - Strategy paper. Stockholm, Sweden: Institute for Futures Studies.

Departamento de Informática do Sistema Único de Saúde DataSUS. (2019). Informações de saúde Tabnet. Brasília, DF: Author.

Diggle, P., Farewell, D., \& Henderson, R. (2007). Analysis of longitudinal data with drop-out: objectives, assumptions and a proposal. Journal of the Royal Statistical Society, 56(5), 499-550. Retrieved from https://doi.org/10.1111/j.14679876.2007.00590.x 
Dollery, B., B. Grant, \& M. Kortt. (2012). Councils in cooperation: shared services in australian local government. Sydney, Australia: Federation Press.

Dourado, D. A., \& Elias, P. E. M. (2011). Regionalization and political dynamics of Brazilian health. Revista de Saúde Pública, 45(1), 1-7. Retrieved from https://doi.org/10.1590/S003489102011000100023

Fávero, L. P. (2015). Análise de dados: modelos de regressão com Excel, Stata e SPSS. Rio de Janeiro, RJ: Campus.

Feiock, R. C. (2004). Metropolitan governance: conflict, competition and cooperation. Washington, DC: Georgetown University Press.

Feiock, R. C. (2007). Rational choice and regional governance. Journal of Urban Affairs, 29(1), 47-63. Retrieved from https://doi.org/10.1111/j.14679906.2007.00322.x

Feiock, R. C. (2013). The institutional collective action framework. Policy Studies Journal, 41(3), 397-425. Retrieved from https://doi.org/10.1111/ psj. 12023

Feiock, R. C., Krause, R. M., \& Hawkins, C. V. (2017). The impact of administrative structure on the ability of city governments to overcome functional collective action dilemmas: a climate and energy perspective. Journal of Public Administration Reserarch and Theory, 27(4), 615-28. Retrieved from https://doi.org/10.1093/jopart/mux021

Fernandes, A. S. A., Pinheiro, L. S., Nascimento, A. B. F., \& Grin, E. J. (2020). An analysis of intermunicipal consortia to provide waste services based on institutional collective action. Revista de Administração Pública, 54(3), 501-23.10.1590/0034761220190237

Gordon, H. S. (1991). The economic theory of a common-property resource: the fishery. Bulletin of Mathematical Biology, 53(1), 231-52. Retrieved from https://doi.org/10.1016/S0092-8240(05)80048-5

Grin, E. J., \& F. L. Abrucio. (2017). La cooperación intermunicipal en Brasil frente al espejo de la historia: antecedentes críticos y la dependencia de la trayectoria de la creación de la ley de los consorcios. Revista de Políticas Públicas, 10(2), 1-27.
Hair, J.F., Jr, Black, W. C., Babin, B. J., Anderson, R. E., \& Tatham, R. L. (2009). Análise multivariada de dados (6a ed.). Porto Alegre, RS: Bookman.

Hardin, G. (2010). The Tragedy of the Commons. Science, 162(3859), 1243-1248. Retrieved from https://doi.org/10.1126/science.162.3859.1243

Hefetz, A., \& Warner, M. E. (2011). Contracting or Public Delivery? The Importance of Service, Market, and Management Characteristics. Journal of Public Administration Research and Theory, 22(2), 289317. Retrieved from https://doi.org/10.1093/jopart/ mur006

Henderson, A. C. (2015). Municipal Shared Services and Consolidation. London, UK: Routledge.

Holzer, M., \& Fry, J. (2011). Shared services and municipal consolidation: a critical analysis. Alexandria, VA: Public Technology Institute.

Holzinger, K. (2003, April). The problems of collective action: a new approach. SSRN Electronic Journal. Retrieved from https://dx.doi.org/10.2139/ ssrn. 399140

Hulst, R., \& Montfort, A. (2007). Inter-municipal cooperation in Europe. Dordrecht, The Netherlands: Springer.

Instituto Brasileiro de Geografia e Estatística. (2019a). Sistema IBGE de recuperação automática SIDRA. Rio de Janeiro, RJ: Author.

Instituto Brasileiro de Geografia e Estatística. (2019b). Perfil dos municípios brasileiros (MUNIC). Rio de Janeiro, RJ: Author.

Johansson, J., Niklasson, L., \& Persson, B. (2015). The role of municipalities in the bottom-up formation of a meta-region in Sweden: drivers and barriers introduction: the role of municipalities in regionalization processes. Scandinavian Journal of Public Administration, 19(4), 71-88.

Kim, K., Andrew, S. A., \& Jung, K. (2017). Public health network structure and collaboration effectiveness during the 2015 MERS outbreak in South Korea: an institutional collective action framework. International Journal Environmental Research and Public Health, 14(1064), 1-15. Retrieved from https://doi.org/10.3390/ijerph14091064 
Lago-Penas, S., \& Martinez-Vazquez, J. (2013). Challenge of local government size. Cheltenham, UK: Edward Elgar Press.

Lei $n^{\circ}$ 8.080, de 19 de setembro de 1990. (1990). Dispõe sobre as condições para a promoção, proteção e recuperação da saúde, a organização e o funcionamento dos serviços correspondentes e dá outras providências. Brasília, DF. Retrieved from http://www.planalto.gov.br/ccivil_03/leis/18080.htm

Lei no 11.107, de 06 de abril de 2005. (2005). Dispõe sobre normas gerais de contratação de consórcios públicos e dá outras providências. Brasília, DF. Retrieved from http://www.planalto.gov. br/ccivil_03/_ato2004-2006/2005/lei/111107.htm

Lima, R. C. A., \& Silveira, R. M., Neto. (2017, January). Secession of municipalities and economies of scale: evidence from Brazil. Journal Regional Science, 58(1), 159-180. Retrieved from https://doi. org/10.1111/jors.12348

Lourenço, E. C., Guerra, L. M., Tuon, R. A., Silva, S. M. C. V., Ambrosano, G. M. B., Corrente, J. E. ... Pereira, A. C. (2014). Variáveis de impacto na queda da mortalidade infantil no Estado de São Paulo, Brasil, no período de 1998 a 2008. Ciência \& Saúde Coletiva, 19(7), 2055-2062. Retrieved from https:// doi.org/10.1590/1413-81232014197.18822013

Matos, F., \& Dias, R. (2012). Intermunicipal cooperation in Paraopeba river Basin. Revista de Administração Pública, 46(5), 1225-1250. Retrieved from https://doi.org/10.1590/S003476122012000500003

Meza, O. D., Grin, E. J., Fernandes, A. S., \& Abrucio, F. L. (2019). Intermunicipal cooperation in metropolitan regions in Brazil and Mexico: does federalism matter? Urban Affairs Review, 55(3), 887-922. Retrieved from https://doi. org/10.1177/1078087418816433

Nascimento, A. B. F. M., \& Fernandes, A. S. A. (2015). Cooperative relations in public consortia for metropolitan areas: analysis of Condiam/PB consortium and greater Recife/PE. Teoria e Prática Em Administração, 5(1), 25-52. Retrieved from https://doi.org/10.21714/2238-104X2015v5i1-20798

Niaounakis, T., \& J Blank, K. (2017). Inter-municipal cooperation, economies of scale and cost efficiency an application of stochastic frontier analysis to dutch municipal tax departments. Local Government Studies, 43(4), 533-554. Retrieved from https://doi. org/10.1080/03003930.2017.1322958

Nicoletto, S. C. S., Cordoni, L., Jr., \& Costa, N. R. (2005). Inter-municipal health consortia: the case of Paraná State, Brazil. Caderno de Saúde Pública, 21(1), 29-38. Retrieved from https://doi.org/10.1590/ S0102-311X2005000100004

Oliveira, C., \& Ganzeli, P. (2013). Intergovernmental relations in education: funding, partnerships, public consortia and arrangements for the development of education. Educação \& Sociedade, 34(125), 10311047. Retrieved from https://doi.org/10.1590/S010173302013000400002

Oliveira, G. N., Freitas, M., Silva, N., \& Carvalho, M. A., Filho. (2011). Profile of the population cared for in a referral emergency unit. Revista Latino Americana de Enfermagem, 19(3), 548-556. Retrieved from https://doi.org/10.1590/S010411692011000300014

Olson, M. (1971). The logic of collective action: public goods and the theory of groups, second printing with a new preface and appendix. London, UK: Harvard University Press. Retrieved from https://doi. org/10.2307/j.ctvjsf3ts

Organização Mundial de Saúde. (2008). Redução das desigualdades no período de uma geração (Relatório final). Lisbon, Portugal: Comissão para os Determinantes Sociais da Saúde.

Ostrom, E. (1990). Governing the commons: the evolution of institutions for collective active. Cambridge, UK: Cambridge University Press.

Ostrom, E. (2005). Understanding institutional diversity. Princeton, New Jersey: Princeton University Press.

Ostrom, E. (2011). Background on the institutional analysis and development framework. Policy Studies Journal, 39(1), 7-27. Retrieved from https://doi. org/10.1111/j.1541-0072.2010.00394.x

Peixoto, B., Foguel, M. N., Pinto, C. C. X., Lima, L., \& Barros, R. P. (2016). Avaliação econômica de projetos sociais. São Paulo, SP: Fundação Itaú Social.

Percoco, M. (2014). Strategic planning and institutional collective action in Italian cities. Public Administration Review, 18(1), 139-158. Retrieved from https://doi.org/10.1080/14719037.2014.969758 
Politi, R. (2014). Desigualdade Na utilização de serviços de saúde entre adultos: uma análise dos fatores de concentração da demanda. Economia Aplicada, 18(1), 117-37. Retrieved from https://doi. org/10.1590/1413-8050/ea379

Rossi, T. R. A., Chaves, S. C. L., Almeida, A. M. F. L., Santos, C. M. L., \& Santana, S. F. (2018). The federal funding of the oral health policy in Brazil between 2003 and 2017. Saúde e Sociedade, 42(119), 82636. Retrieved from https://doi.org/10.1590/01031104201811903

Scholz, J. T., Feiock, R. C., \& Ahn, T. K. (2006). Policy networks and institutional collective action: a research agenda (Working Group on Interlocal Services Cooperation). Detroit, MI: DigitalCommons@ WayneState. Retrieved from https://digitalcommons. wayne.edu/interlocal_coop/16/

Secretaria do Tesouro Nacional. (2019). Sistema de Informações Contábeis e Fiscais do Setor Público Brasileiro. Brasília, DF: Author.

Silvestre, H. C., Marques, R. C., Dollery, B., \& Correia, M. C. (2019). Is cooperation cost reducing? An analysis of public - public partnerships and intermunicipal cooperation in Brazilian local government public - public partnerships and inter-municipal. Local Government Studies, 46(1), 68-90. Retrieved from https://doi.org/10.1080/03003930.2019.1615462

Siqueira, M. S., Rosa, R. S., Bordin, R., \& Nugem, R. C. (2017). Internações por doenças relacionadas ao saneamento ambiental inadequado na rede pública de saúde da região metropolitana de Porto Alegre, Rio Grande do Sul, 2010-2014. Epidemiologia e Serviços de Saúde, 26(4), 795-806. Retrieved from https://doi.org/10.5123/S1679-49742017000400011

Tavares, A. F., \& Feiock, R. C. (2018). Applying an institutional collective action framework to investigate intermunicipal cooperation in Europe. Perspectives on Public Management and Governance, 1(4), 299-316. Retrieved from https:// doi.org/10.1093/ppmgov/gvx014

Teles, F., \& Swianiewicz, P. (2018). Inter-municipal cooperation in Europe: institutions and governance. Basingstoke, UK: Palgrave.
Thum, M. A., Baldisserotto, J., \& Celeste, R. K. (2019). e-SUS AB use and factors associated with recording primary care procedures and consultations in Brazilian municipalities. Cadernos de Saúde Pública, 35(2), 1-13. Retrieved from https://doi. org/10.1590/0102-311X00029418

Tomkinson, R. (2007). Shared services in local government. Aldershot, UK: Gower Publishing.

Tribunal Superior Eleitoral. (2019). Eleições anteriores. Brasília, DF: Author.

Viacava, F., Oliveira, R., Carvalho, C. C., Laguardia, J., \& Bellido, J. G. (2018). SUS: supply, access to and use of health services over the last 30 years. Ciência \& Saúde Coletiva, 23(6), 1751-62. Retrieved from https://doi.org/10.1590/141381232018236.06022018

Voorn, B., Genugten, M. V., \& Thiel, S. V. (2019, September). Multiple Principals, Multiple Problems: Implications for Effective Governance and a Research Agenda for Joint Service Delivery. Public Administration, 97(3), 671-685. Retrieved from https://doi.org/10.1111/padm.12587

Wolfart, G. A., Silva, G. M., \& Schmidt, C. M. (2013). Selective incentives through the intermunicipal health consortium of the west coast of Paraná State. Revista Brasileira de Planejamento e Desenvolvimento, 2(1), 59-71. Retrieved from https:// doi.org/10.3895/rbpd.v2n1.3086

Wooldridge, J. M. (2012). Introductory econometrics: a modern approach ( $5 \mathrm{a}$ ed.). Mason, Ohio: SouthWestern Cengage Learning.

Yi, H., \& Cui, C. (2018). Coping with functional collective action dilemma: functional fragmentation and administrative integration. Public Management Review, 21(7), 1052-1075. Retrieved from https:// doi.org/10.1080/14719037.2018.1544271

Zioni, F., \& Westphal, M. F. (2007). O enfoque dos determinantes sociais de saúde sob o ponto de vista da teoria social. Saúde e Sociedade, 16(3), 26-34. Retrieved from https://doi.org/10.1590/S010412902007000300004 


\section{Alex Bruno Ferreira Marques do Nascimento}

https://orcid.org/0000-0001-9860-7350

Doctor in Administration from Federal University of Rio Grande do Norte (UFRN); Adjunct Professor at Federal University of Campina Grande (UFCG/CDSA/UAGESP) and Postgraduate Program in Administration (PPGA/UFCG).E-mail: alex.bruno@professor.ufcg.edu.br

\section{Antônio Sérgio Araújo Fernandes}

https://orcid.org/0000-0002-4171-7759

Ph.D. in Political Science from University of São Paulo (USP); Post Doctorate in Public Administration from University of Texas at Austin, Lyndon B. Johnson School of Public Affairs; Associate Professor at the Federal University of Bahia (UFBA), School of Administration, Postgraduate Center in Administration.

E-mail: antoniosaf@ufba.br

\section{Hironobu Sano}

https://orcid.org/0000-0002-4955-8895

Ph.D. in Public Management and Government at Getulio Vargas Foundation (FGV EAESP); Associate professor at the Department of Public and Social Management at the Federal University of Rio Grande do Norte (UFRN). E-mail: hironobu.sano@ufrn.br

\section{Eduardo José Grin}

https://orcid.org/0000-0002-0488-8487

Ph.D. in Public Administration and Government at Getulio Vargas Foundation (FGV EAESP); Professor from São Paulo School of Business Administration at Getulio Vargas Foundation (FGV EAESP).

E-mail: eduardo.grin@fgv.br

\section{Hugo Consciência Silvestre}

https://orcid.org/0000-0001-7654-6577

Ph.D. in Administration Science, with specialization in Public Management at the University of Minho; Associate Professor from the Institute of Applied Social Sciences at the University of International Integration of Afro-Brazilian Lusofonia (UNILAB). E-mail hmcsilvestre@unilab.edu.br 